\title{
The Uniform Principal and Income Act
}

$T_{\text {HE Uniform Principal and Income Act, }{ }^{1} \text { approved by the National }}$ has been adopted in but five states, none of them of the first rank in wealth or commerce. ${ }^{2}$ Modified versions have been adopted in three others. Though this slow uptake may well be ascribed to causes other than imperfections, real or imaginary, in the Act, it does suggest possible dissatisfaction with certain of its provisions and seems to justify an inquiry which is perhaps overdue. ${ }^{3}$

It should be unnecessary to say that by this inquiry no reflection is intended upon the draftsmanship of the Act. Its text bears testimony to the competence of its authors, which their personnel confirms. ${ }^{4}$ Prepared for the most part before the depression, the Act received the imprimatur of its sponsors when that debacle, the source of an unparalleled though grievous experience, was only well under way. That experience bears directly upon the kind of problem with which such an act must deal. For these reasons the re-examination of certain of its proposed solutions, which is the purpose of these comments, seems permissible.

The trust aspects of the Act will be dealt with exclusively here.

11938 Supp. to vol. 9, Unif. Laws Ann., 201.

2 Florida (1937); North Carolina (1937); Oregon (1931); Utah (1939); Virginia (1936). In addition to these states, which have adopted the Act verbatim or in substance, may be noted the following: Connecticut (1939) (omits $\$ \S 4,11,12$ (4)-17) ; Louisiana (1938) (omits \$§ 1, 2, 13-17); Maryland (1939) (omits \$\$ 7-11). See Prentice-Hall Trust Serv. $\llbracket 3945, \mathrm{n} .1$.

3 The comment which the Act has evoked among reviewers has been nuainly expository rather than analytical. Dealing with it noore or less (in some cases only incidentally) are: Beers, The Effect on Connecticut Law of the Proposed Uniform Principal and Income Act (1939) 13 CoNN. B. J. 3; Cbapin, The Uniform Principal and Income Act in Oregon (1936) 15 ORE. L. Rev. 393; Clark, Analysis of Proposed Uniform Principal and Income Act (1930) 50 Trust CoMpanIes 383; Clark, Interpretation of Proposed Uniform Principal and Income Act (1932) 54 ibid. 723; Faught, Statutory Solution of the Problem of Allocation Between Life Tenant and Remainderman (1937) 11 TEMPLE L. Q. 139; Graubert, Clarifying Rights of Life Tenant and Remainderman (1936) 63 Trust CoMpanIEs 167; Isaacs, Principal-Quantum or Res? (1933) 46 Harv. L. Rev. 776, 781; Wisdom, A Trust Code in the Civil Law, Based on the Restatement and Uniform Acts: The Loncisiana Trust Estates Act (1938) 13 TULANE L. REv. 70; Note (1932) 32 Cor. L. Rev. 118. See Earle, Inequisities of Uniform Principal and Income Act (1937) 65 Trust CoMpanIES 209. Governor Earle sees a sacial issue in the Act.

4 Hon. Charles E. Clark, then dean of Yale Law School, now judge of the Circuit Court of Appeals of the Second District, was draftsman. See (1931) 56 A.B.A. REP. 41. This meeting gave the Act routine approval. Professor Bogert was a member of the supervising committee. The writer is indebted to Dean Clark far some of the citations in note 3, supra; also for information as to the reasons for certain provisions of the Act. 
For convenience of reference, the statute as proposed by the Commissioners is reprinted in the footnotes. Specific reference will be made only to certain of its provisions. Since the subject matter requires concreteness, in that interest a tentative redraft of certain sections is offered for consideration.

Accepting the principle underlying all similar legislation, that clarity and uniformity are needed, ${ }^{5}$ and that simplicity is to be attained where possible, the present Act has another aspect; naniely, that effect is to be given to a presumed intent on the part of settlors, where not inconsistent with other objectives. This element, and the somewhat arbitrary standards by which in some instances it is measured in order to reach desired results, assumes great importance in the cases. ${ }^{3}$ In the average case-and a statute must deal with averages-trusts are created primarily for the benefit of life tenants. This principle, confirmed by practical experience and increasingly recognized judicially, ${ }^{7}$ is the connecting link through which an attenipt will be made to give coherence to these comments.

Recognition of a principle is one thing; giving it practical effect is another. The draftsman must take into account that although a trustee may be convinced of a general intent favorable to the imcome beneficiary, self protection will impel him to the opposite direction if any doubt exists, since only by resolving doubts against the life tenant is the ability to account to remaindermen preserved. This may account for an explicitness in some of the provisions to be suggested, which might otherwise appear to be extreme.

As to section 1, the writer has no comment. ${ }^{8}$ Section 2 very properly gives the settlor authority to delegate to "the trustee or

5 See articles by Clark, loc. cit. supra note 3 ; prefatory note to the Uniform Principal and Income Act.

${ }^{6} E . g .$, see the cases dealing with unproductive property in note 60 , infra.

7 Lawrence v. Littlefield (1915) 215 N. Y. 561, 109 N. E. 611 ; Furmiss v. Cruikshank (1921) 230 N. Y. 495, 130 N. E. 625; Nirdlinger's Estate (1938) 331 Pa. 135, 200 At1. 656, 116 A. L. R. 1350, (1938) 52 HARv. L. REv. 331 [previous opinions reported in (1927) 290 Pa. 457, 139 Atl. 200, (1928) 56 A. L. R. 1303; (1937) 327 Pa. 171, 193 Atl. 33, (1937) 51 HARv L. Rev. 175]; Horton v. Briggs (1934) 176 Wash. 502, 29 P. (2d) 925; see 4 Bogert, Trusts \& Trustees (1935) \& 826, n. 74. Cf. Dean Clark's views expressed in his first cited Trust Companies article, loc. cit. supra note 3.

8 UNIFORM ACT \& 1: "Definition of terms. 'Principal' as used in this act means any realty or personalty which has been so set aside or limited by the owner thereof or a person thereto legally empowered that it and any substitutions for it are eventually 
other person" a discretion to make determinations affecting rights in principal and income. ${ }^{9}$ To avoid the tendency toward practical nullification of a similar provision exhibited in a recent lower court decision in New York ${ }^{10}$ it might be desirable to adopt the rule of Dumaine v. Dumaine ${ }^{11}$ and provide that the designated person's determination shall be conclusive in the absence of bad faith or arbitrary action. This suggestion is incorporated in a proposed addition to section $2 .^{12}$

II

Section 3 of the Uniform Act ${ }^{13}$ says: "... dividends on corporate shares payable other than in shares of the corporation itself, ... shall be deemed income...."

to be conveyed, delivered or paid to a person, while the return therefrom or use thereof or any part of such return or use is in the meantime to be taken or received by or held for accumulation for the same or another person;

"Income' as used in this act means the return derived from principal;

"'Tenant' as used in this act means the person to whom income is presently or currently payable, of [or] for whom it is accumulated or who is entitled to the beneficial use of the primcipal presently and for a time prior to its distribution;

"'Remaindernnan' as used in this act means the person ultimately entitled to the principal, whether named or designated by the terms of the transaction by which the principal was established or determined by operation of law;

"'Trustee' as used in this act includes the original trustee of any trust to which the principal may be subject and also any succeeding or added trustee."

${ }^{9}$ UNIFORM ACT § 2: "Applieation of the act-powers of settlor. This act shall govern the ascertainment of income and principal, and the apportionment of receipts and expenses between tenants and remaindennen, in all cases where a principal has heen established with or, unless otherwise stated hereinafter, without the interposition of a trust; except that in the establisbment of the principal provision may be made touching all matters covered by this act, and the person establishing the principal may himself direct the manner of ascertainment of income and principal and the apportionment of receipts and expenses or grant discretion to the trustee or other person to do so, and such provision and direction, where not otherwise contrary to law, shall control notwithstanding this act."

10 In re Talbot's Will (Surr. Ct. N. Y. 1939) 9 N. Y. S. (2d) 806, (1939) 52 HARV. L. REV. 1369.

11 (Mass. 1938) 16 N.E. (2d) 625, (1939) 118 A. L. R. 834, Note ibid. 842, 843; see Colt v. Duggan (D. N. Y. 1938) 25 Fed. Supp. 268.

$12 \S 2$ [Suggested additton]: The exercise by the trustee or other designated person of such discretionary power, if in good faith and according to his best judgment, shall be conclusive, irrespective of whether it may be in accordance with the determination which the court having jurisdiction would have made.

13 UNTFORAC ACr \& 3: "Income and principal-disposition. (1) All receipts of money or other property paid or delivered as rent of realty or hire of personality or dlvidends on corporate shares payable other than in shares of the corporation itself, or interest on money loaned, or interest on or the rental or use value of property wrongfully withheld or tortiously damaged, or otherwise in return for the use of principal, shall be deemed income unless otherwise expressly provided in this act. 
Up to 1931, so far as the writer's observation goes, the courts following the Massachusetts rule relative to stock dividends had admitted no important exceptions to the rule that such dividends are principal if paid in shares of the corporation itself. ${ }^{14}$ Since that time, however, the Supreme Court of the United States, as firmly committed as any to that rule, ${ }^{15}$ has recognized that a dividend paid out of earnings, even though payable in the corporation's own shares, may be income where the new shares give the stockholder an interest different in character from that represented by his previous holdings. ${ }^{16}$

This doctrine, without impairing the practical operation of the Massachusetts rule, alleviates its necessary harshness to some extent, and may well be adopted. Its adoption will require a slight change in section $3,{ }^{17}$ elaborated more fully in section 5 (1) below. For

“(2) All receipts of money or other property paid or delivered as the consideration for the sale or other transfer, not a leasing or letting, of property forming a part of the principal, or as a repayment of loans, or in liquidation of the assets of a corporation, or as the proceeds of property taken on eminent domain proceedings where separate awards to tenant and remainderman are not made, or as proceeds of insurance upon property forming a part of the principal except where such insurance has been issued for the benefit of either tenant or remainderman alone, or otherwise as a refund or replacement or change in form of principal, shall be deemed principal unless otherwise expressly provided in this act. Any profit or loss resulting upon any change in form of principal shall enure to or fall upon principal.

"(3) All income after payment of expenses properly chargeable to it shall be paid and delivered to the tenant or retained by him if already in his possession or held for accumulation where legally so directed by the terms of the transaction by which the principal was established; while the principal shall be held for ultimate distribution as determined by the terms of the transaction by which it was established or by law."

On profits or losses on principal account, see Commissioner v. Waterbury (C. C. A. 2d, 1938) 97 F. (2d) 383; Coit v. Duggan, supra note 11; In re Clarke's Will (Minn. 1939) 284 N. W. 876; Brown v. Sperry (Miss. 1938) 181 So. 734; Matter of Hagen (1933) 262 N. Y. 301, 186 N. E. 792 ; In re Roebken's Will (Wis. 1939) 283 N. W. 815; RESTATElateNT OF THE LAW OF TRUSTS (Am. L. Inst. 1935) $\S 233$; but see Matter of Lott (1937) 251 App. Div. 333, 296 N. Y. Supp. 43.

${ }_{14}$ No analysis of this familiar question seems necessary here. For the cases see Note (1936) 101 A. L. R. 1379, and earlier notes there cited. See 4 BOGERT, op. cit. supra note 7, $\S 847-854$; Restatement of THE LAW OF Trusts (Am. L. Inst. 1935) $\S 236$, comments $\mathrm{h}$, $\mathrm{u}$.

15 Gibbons v. Mahon (1890) 136 U. S. 549; Eisner v. Macomber (1920) 252 U. S. 189.

16 Koshnald v. Helvering (1936) 298 U. S. 441; Helvering v. Gowran (1937) 302 U. S. 238 ; cf. Burns v. Hines (1939) 298 III. App. 563, 19 N. E. (2d) 382.

$17 \& 3$ (1) [Suggested revision]: Delete from the present context the reference to dividends on corporate shares, adding at the end of the subsection a provision in substance as follows: Dividends on corporate shares, payable in stock or otherwise, shall be deemed income except as provided in section 5 . 
practical reasons, in the suggested redraft of the latter section, incorporating this change, a rule of thumb, believed to be in most instances the substantial equivalent of the principle stated by the Supreme Court, has been used as a vehicle for carrying that principle into effect.

\section{III}

Section $4 .^{18}$ Apportionment of income. (a) Income payable periodically. Trust income is frequently made payable at periodical intervals - inonthly, quarterly, semi-annually, etc. Do provisions relative to periodical payment affect the substantive rights of the tenant or are they primarily for convenience? Upon this question depends whether the estate of the life tenant, if he dies during one of the stated periods, is entitled to nothing because of his failure to survive the appointed date or is entitled to a proportionate share

18 UNRFORAS ACT \& 4: "Apportionment of income. Whenever a tenant shall have the right to income from periodic payments, which shall include rent, interest on loans, and annuities, but shall not include dividends on corporate shares, and such right shall cease and determine by death or in any other manner at a time other than the date when such periodic payments should be paid, he or his personal representative shall be entitled to that portion of any such income next payable which amounts to the same percentage thereof as the time elapsed from the last due date of such periodic payments to and including the day of the determination of his right is of the total period during which such income would normally accrue. The remaining incoine sball be paid to the person next entitled to income by the terms of the transaction by which the principal was established. But no action shall be brought by the trustee or tenant to recover such apportioned income or any portion thereof untll after the day on which it would have become due to the tenant but for the determination of the right of the tenant entitled thereto. The provisions of this section shall apply whether an ultimate remainderman is specifically named or not. Likewise when the right of the first tenant accrues at a time other than the payment dates of such periodic payments, he shall only receive that portion of such income which amounts to the same percentage thereof as the time during which he has been so entitled is of the total period during which such income would normally accrue; the balance sball be a part of the principal."

Apportionment of interest: Kahn v. Wells-Fargo Bank \& Union Trust Co. (1933) 137 Cal. App. 775, 27 P. (2d) 672; Wilmington Trust Co. v. Chapman (1934) $20 \mathrm{Del}$. Ch. 67, 171 Atl. 222, aff'd (1934) 20 Del. Ch. 454, 180 Atl. 927 (interests on bonds apportionable) ; Matter of Watson (1933) 262 N. Y. 284, 186 N. E. 787 (interest on investments generally). Contra: Union Safe Deposit \& Trust Co. v. Dudley (1908) $104 \mathrm{Me}$. 297, 72 Atl. 166; Dexter v. Phillips (1876) 121 Mass. 178, (1878) 23 Am. Rep. 261.

Apportionment of dividends from day to day: Bankers Trust Co. of N. Y. v. Lobdell (1934) 116 N. J. Eq. 363, 173 Atl. 918 (regular dividends apportioned). At common law dividends were not apportionable. Given's Estate (1936) $323 \mathrm{~Pa} .456$, 185 Atl. 778. On apportionment see also note 23 , infra.

First Nat. Bank \& Trust Co. v. Baker (1938) 124 Conn. 577, 593, 1 A. (2d) 283, 290 (accrued income at life tenant's death goes to his estate). 
of the income earned or accrued since the last preceding specified date. ${ }^{19}$

The sensible rule appears to be that such provisions have nothing to do with substantive rights but are directory merely. The point is a minor one, but might well be the subject of a clarifying clause.

(b) Income "received" or "derived" from the trust. Some decisions show a tendency to give small and probably inadvertent departures from usual phraseology undue prominence in determining the rights of successive beneficiaries inter se. For example in Estate of Lockhart," where income "received or derived" from the trust was to go to the widow, it was held her estate had no right to income merely accrued, not actually received by the trustee at date of her death. ${ }^{21}$ Though courts, fumbling for evidences of intent in order to reconcile conflicting demands, may take these trivial circumstances into account, it would seem that a statute might well ignore them.

The above and a proposed rearrangement of the first sentence of section $4^{22}$ are incorporated in a suggested partial revision of that section. ${ }^{23}$

19 Estate of Lockhart (1937) 21 Cal. App. (2d) 574, 69 P. (2d) 1001; Cromwell v. Converse (1928) 103 Conn. 412, 143 Atl. 416; Union Safe Deposit \& Trust Co. v. Dudley, supra note 18; Welch v. Apthorp (1909) 203 Mass. 249, 89 N. E. 432; Commercial Trust Co. of N. J. v. Spiegelberg (1934) 117 N. J. Eq. 171, 175 Atl. 164, aff'd, (1936) 119 N. J. Eq. 376, 182 Atl. 875; Matter of Lamb (1918) 182 App. Div. 180, 169 N. Y. Supp. 614, aff'd, (1918) 224 N. Y. 577, 120 N. E. 866; Davidson's Estate (1926) $287 \mathrm{~Pa} .354,135$ Atl. 130; 4 BOGERT, op. cit. supra note $7, \S 816 ; 2$ PERRY oN Trusrs (7th ed. 1929) $\$ \$ 556 \mathrm{a}, 556 \mathrm{~b}, 556 \mathrm{c}$.

20 Supra note 19, at 579, 69 P. (2d) at 1004. A draft of a principal and income act was approved by California trust companies in 1938 which applied the Lockhart rule in all cases, i.e., cut off a tenant's rights (except as to income actually in the trustee's hands) as of tbe moment his estate ends. There is much to be said for tbis rule.

21 For similar enuphasis on "derived" see Given's Estate, supra note 18.

22 The wording of the first sentence of section 4 seems a little obscure. Literally, the rule which it states would not apply at all if the income includes dividends. Presumably this was not the intent.

$23 \$ 4$ [Suggested revision]: Whenever a tenant shall have the right to the income of, or accrued upon or received or derived from, a principal, including a right to annuities, and such right shall cease and determine by death or in any otber manner at a time other than the date when such periodic payments should be made, he or his personal representative shall be entitled to that portion of any such annuity next payable, and of any such incoune accrued before his right to income ceases, but received by the trustee within one year thereafter, insofar as sucb incone may be derived from rents and interest but not from dividends on corporate shares, which amounts to the same percentage thereof [and then as in the present Act]. Insert after the first sentence: The foregoing rule shall apply whether the income is directed to be paid to the tenant as and when received or monthly, quarterly, annually or at any other stated period. 
(c) Should there be a time limit on a tenant's rights to income accrued but uncollected during his tenancy? Suppose when a particular estate ends there is interest accrued which is not collected until years later. Conceding the former tenant's theoretical rights, there is a limit beyond which it is impracticable to keep these matters open. In In re Spear's Estate ${ }^{24}$ the Pennsylvania court recently held a deceased life tenant's estate was not entitled to an accounting for accrued interest on a defaulted mortgage where impracticable because of long delay. If a life tenant is to be given any rights at all in income accrued but not collected when his tenancy ceases - a point as to which settlors will be found to be absolutely indifferent-it might not be unreasonable to prescribe one year as a limit beyond which a tenant or his estate cannot go in demanding an accounting of items collected after, but accruing before, the end of his tenancy. This suggestion is made in the proposed revision of section $4 .^{25}$

\section{IV}

Section 5. Corporate dividends and share rights. Section 5 (1). (a) Stock dividends. Reasons have already been pointed out for the belief that the Uniform Act ${ }^{26}$ goes too far in giving to principal

Apportionment of regular dividends on a per diem basis as between successive estates is provided for by statute in some states. See Zell v. Safe Deposit \& Trust Co. of Baltinore (Md. 1938) 196 Atl. 298, 299; Nirdlinger's Estate (1937) 327 Pa. 171, 175, 193 Atl. 33, 36, (1937) 51 HaRv. L. REv. 175. See also note 18, suppra.

24 (Pa. 1939) 3 A. (2d) 189.

25 See note 23 , supra.

26 UNIFORM ACT $\$ 5$ : "Corporate dividends and share rights. (1) All dividends on shares of a corporation forming a part of the principal which are payable in the shares of the corporation shall be deemed principal. Subject to the provisions of this section, all dividends payable otherwise than in the shares of the corporation itself, including ordinary and extraordinary dividends and dividends payable in shares or other securities or obligations of corporations other than the declaring corporation, shall be deemed income. Where the trustee shall have the option of receiving a dividend either in cash or in the shares of the declaring corporation, it shall be considered as a casls dividend and deemed income, irrespective of the choice made by the trustee.

"(2) All rights to subscribe to the shares or other securities or obligations of a corporation accruing on account of the ownerslip of shares or other securities in such corporation, and the proceeds of any sale of such rights, shall be deemed principal. All rights to subscribe to the shares or other securities or obligations of a corporation accruing on account of the ownership of shares or other securities in another corporation, and the proceeds of any sale of such rights, shall be deemed income.

"(3) Where the assets of a corporation are liquidated, amounts paid upon corporate shares as cash dividends declared before sucls liquidation occurred or as arrears of preferred or guaranteed dividends shall be deemed income; all other amounts paid upon corporate shares on disbursement of the corporate assets to the stockholders shall 
all stock dividends payable in the declaring corporation's own shares. To the extent that this suggestion may be favorably regarded, it will be necessary to revise section 5 (1). ${ }^{2 \pi}$

(b) Apportionment of new stock received in connection with reorganizations, etc. There are certain instances where stock, though not labeled as a dividend, is nevertheless that in substance, and should go to incoine. For exainple, a corporation having outstanding preferred stock on which dividends are in arrears and having a surplus account sufficient, but cash insufficient, to pay them, reorganizes in such nanner that this stock is retired and new preferred stock issued

be deemed principal. All disbursements of corporate assets to the stockholders, whenever made, which are designated by the corporation as a return of capital or division of corporate property shall be deemed principal.

"(4) Where a corporation succeeds another by merger, consolidation or reorganization or otherwise acquires its assets, and the corporate shares of the succeeding corporation are issued to the shareholders of the original corporation in like proportion to, or in substitution for, their shares of the original corporation, the two corporations shall be considered a single corporation in applying the provisions of this section. But two corporations shall not be considered a single corporation under this section merely because one owns corporate shares of or otherwise controls or directs the other.

"(5) In applying this section the date when a dividend accrues to the person who is entitled to it shall be held to be the date specified by the corporation as the one on which the stockholders entitled thereto are determined, or in default thereof the date of declaration of the dividend."

Cash dividends: Zell v. Safe Deposit \& Trust Co. of Baltimore, supra note 23; Heyn v. Fidelity Trust Co. (Md. 1938) I A. (2d) 83, 91 (cash dividends earned and paid after testator's death, to income; other dividends to corpus to extent. they encroached on surplus at testator's death); Matter of Postley (1937) 251 App. Div. 469,296 N. Y. Supp. 627 (all ordinary dividends to income thougb designated "extra"); Nirdlinger's Estate, supra note 23. See RestatemIENT of the Law of Trusts (Ain. L. Inst. 1935) § 236.

Dividends payable in shares of corporations other than declaring corporation: Whiting v. Hagey (1937) 366 Ill. 86, 7 N. E. (2d) 885; City Bank Farmers Trust Co. v. Ernst (1934) 263 N. Y. 342 , 189 N. E. 241.

Stock rights: City Bank Fanners Trust Co. v. Wylie (1937) 273 N. Y. 304, 7 N. E. (2d) 241.

When right to dividend accrues: Smith v. Taecker (1933) 133 Cal. App. 351, 24 P. (2d) 182; Union \& New Haven Trust Co. v. Watrous (1929) 109 Conn. 268, 146 Att. 727 (holders of record date governs right to dividend); Opperınan's Estate (1935) $319 \mathrm{~Pa} .455,179$ Atl. 729 (date of declaration governs in absence of "holders of record" date, though not payable until later). See Note (1929) 60 A.L. R. 703.

$2 \pi \S 5$ [Suggested revision]: (1) All dividends on shares of a corporation forming a part of the principal which are payable in shares of the corporation of the same kind and rank as the stock on which such dividend is paid, and dividends payable in shares of whatever kind or rank, to the extent that they represent a capitalization of surplus not derived from earnings, shall be deemed principal. Subject to the provisions of this section, all dividends payable otherwise than in such shares, including ordinary and extraordinary dividends [and then as in the present Act]. 
bearing a different, usually a lower, rate. New stock, either common or a subordinate class of preferred, is issued in lieu of or as representing the dividends in arrears. Where the new stock is intended by the issuing corporation - and on this point any action or expression on the part of the corporation should be conclusive-as in lieu of or as a substitute for the dividends accrued on the old, such new or additional stock should be considered income.2s This seems to be a special case calling for the application of the exception already mentioned to the Massachusetts rule. Manifestly, the new stock, of whatever kind, should go to income only where it capitalizes earned surplus, not where it is issued against a surplus artificially created by reducing stated capital. ${ }^{29}$

(c) Section 5 (3). Liquidating dividends. Certainty is the objective in undertakings of this kind. Recognizing that "liquidation" is a disputable fact or status, the subsection provides that disbursements designated by the corporation as a return of capital are corpus. This is satisfactory as far as it goes. The most informed source as to whether a particular dividend is a return of capital or a distribution of income is the corporation itself, and its statements respecting these matters are fully as likely to be correct as are the conclusions of trustees or courts, often far removed in space and time. ${ }^{30}$ Litigation

28 Illustrations: Rearrangement of capitalization of Goodyear Tire \& Rubber Co. (Ohio, 1937); reorganization of Crown Zellerbach Corp. (Nevada, 1937) and Crown Willamette Paper Co. (Delaware, 1937). For another reorganization of the same general type, see Wheeling Steel Corp. (Delaware, 1937). For another type of recapitalization, see Ainerican Crystal Sugar Co. (New Jersey, 1935) (new preferred for old, including unpaid dividends on latter; the whole would be corpus under Massachusetts rule). See also Southern Ohio Sav. Bank \& Trust Co. v. Hayward (1937) 9 Ohio Ops. 333, (1937) 65 TRust CoMpaniss 642 (preferred stock in arrears called in and new preferred and common stock issued. Held, all new stock goes to corpus). For an illustration of the kind of reorganization in question, though involving no question of life tenant and remainderman, see Matter of Kinney (1939) 279 N. Y. 423, 18 N. E. (2d) 645; (1939) 52 HARv. L. REv. 1011.

29 In re Lloyd's Estate (Surr. Ct. N. Y. 1939) 12 N. Y. S. (2d) 292 (such a dividend goes to corpus regardless of direction that all dividends, even those encroaching on principal, go to income); Opperman's estate, sulpra note 26; see United States Trust Co. v. Heye (1918) 224 N. Y. 242, 120 N. E. 645 (issuance of new stock, not as dividend, but as substitute for old, raises no question as between hife tenant and remainderman).

30 Estate of Duffill (1919) 180 Cal. 748, 755, 183 Pac. 337, 339, illustrates a seeming lack of realism in dealing with a similar problem. And see Will of Jenkins (1929) 199 Wis. 131, $225 \mathrm{~N}$. W. 733. For a view believed to be more practical, giving reasonable weight and attaching appropriate presumptions to corporate action, see Whiting $\mathrm{v}$. Hagey, supra note 26; Gray v. Heinenway (1929) 268 Mass. 515, 168 N. E. 102; Creed v. McAleer (1931) 275 Mass. 353, 175 N. E. 761, (1932) 80 A. L. R. 1117; Lowrey v. Farmers Loan \& Trust Co. (1902) 172 N. Y. 137, 64 N. E. 796; United States Trust Co. v. Heye, supra note 29 ; Bourne v. Boume (1925) 240 N. Y. 172, 148 N. E. 180. 
is not the only means of acquiring knowledge. The partial recognition of this principle in section 5 (3) may very well be carried a step further and the trustee be given the right to rely upon statements of the corporation respecting the source of dividends in all cases where that fact is relevant. ${ }^{31}$ A draft of a subsection embodying this suggestion is presented in the footnotes. ${ }^{32}$

\section{$\mathrm{V}$}

Section 6. Premium and discount bonds. Since the Uniform Act was prepared new forms of government obligation issued on a discount basis have becoine current. These include treasury. bills ${ }^{33}$ and United States savings bonds. ${ }^{34}$ It is conceivable that similar bonds may be issued by other agencies. In the case of savings bonds the purchaser pays presently 75 per cent of the face amount and receives the latter amount if he keeps the bond ten years, having the privilege of presenting it for redemption according to a fixed scale prior to that time. Savings bonds are proper investments in certain cases, for example, trusts for accumulation for a fixed period, ${ }^{35}$ and have been widely used in trust accounts. ${ }^{36}$ Similar bonds with short maturities have a wider field of utility.

Where investinents of this kind are held in trusts, there can be no objection to distribution as income, upon maturity or surrender of the bond, of the accretion upon the original investment. Under section

31 This does not mean, of course, that the ultimate legal question of what is income or capital as between life tenant and remainderman is determined by the corporation. See Pratt v. Ladd (1930) 253 N. Y. 213, 170 N. E. 895. Principal and income are not ahsolutes. Equitable Trust Co. v. Prentice (1928) 250 N. Y. 1, 11, 164 N. E. 723, 725. But the corporation should be able to determine facts relative to its own assets and earuings.

32 5 [Suggested revision] : Add a new subsection (6) as follows: The trustee or tenant may rely upon the statement of the paying corporation as to whether dividends are paid from profits or earnings or are a return of capital or division of corporate property, and as to any other fact, relevant under any provision of this act, concerning the source or character of dividends or dishursements of corporate assets.

3346 Stat. (1929) 19, 20, 31 U. S. C. (1934) §§ 754 (a), 754 (b), as amended 49 StaT. (1935) 20, 31 U. S. C. Supp. IV (1938) § 754 (a).

3449 STAT. (1935) 21, 31 U.S. C. SUPp. IV (1938) § 757 (c).

35 See Restatearent of the LaW of Trusts (Am. L. Inst. 1935) § 233, comment d.

36 The Treasury Department advises that the total sales to "fiduciaries" from March 1, 1935, date of first issuance, up to and including July 17, 1939, were of a maturity value of $\$ 160,0 \$ 6,675$. 
$6^{37}$ it would seem that this accretion-it is really interest-on obligations of this type would go to corpus. A clause intended to remove doubt on this point is proposed in the footnotes. ${ }^{38}$ Section $7^{30}$ and section $8^{40}$ are set forth below.

VI

Section 9. Disposition of natural resources.11 Referring, then, first to section 10, which deals with the related topic of principal

37 UNIFORM ACT § .6: "Premium and discount bonds. Where any part of the principal consists of bonds or other obligations for the payment of money, they shall be deemed principal at their inventory value or in default thereof at their market value at the time the principal was established, or at their cost where purchased later, regardless of their par or maturity value; and upon their respective maturities or upon their sale any loss or gain realized thereon shall fall upon or enure to the principal."

Premiums and discounts: Estate of Gartenlaub (1921) 185 Cal. 648, 198 Pac. 209, (1922) 16 A.L. R. 520 (amortization rule applied) ; In re Account of Houston's Trustees (1933) 19 Del. Ch. 207, 165 Atl. 132 (no accumulations of discounts in favor of income); Liberty Nat. Bank \& Trust Co. v. Loomis (Ky. 1938) 121 S. W. (2d) 947 (amortization rule disapproved on practical grounds); Old Colony Trust Co. v. Comstock (1935) 290 Mass. 377, 195 N. E. 389, (1936) 101 A.L. R. 1, Note ibid. 7.

$38 \S 6$. [Suggested addition]: Where any part of the principal consists of a bond or other obligation for the payment of money, bearing no stated interest but redeemable at maturity or a future time at an amount in excess of the amount in consideration of which it was issued, such accretion, as and when realized, shall enure to income.

For a recent statute (1939) adopting this principle, sce Dex. Rev. Code (1935) \& 4401 (A).

39 UndForar Acr \& 7: "Principal used in business. (1) Whenever a trustee or a tenant is authorized by the terms of the transaction by which the principal was established, or by law, to use any part of the principal in the continuance of a business which the original owner of the property comprising the principal bad been carrying on, the net profits of such business attributable to such principal shall be deemed income.

"(2) Where such business consists of buying and selling property, the net profits of any period shall be ascertained by deducting from the gross returns during and the inventory value of the property at the end of such period, the expenses during and the inventory value of the property at the beginning of such period.

"(3) Where such business does not consist of buying and selling property, the net income shall be computed in accordance with the customary practice of such business, but not in such way as to decrease the principal.

"(4) Any increase in the value of the principal used in such business shall be decmed principal, and all losses in any one calendar year, after the income from such business for that year has been exhausted, shall fall upon principal."

40 UNIFORM ACT \& 8: "Principal comprising animals. Where any part of the principal consists of animals employed in business, the provisions of section 7 shall apply; and in other cases where the animals are held as a part of the principal partly or wholly because of the offspring or increase which they are expected to produce, all offspring or increase shall be deemed principal to the extent necessary to maintain the original number of such animals and the remainder shall be deemed income; and in all other cases such offspring or increase shall be deemed income.

41 For the authorities see Notes (1926) 43 A.L. R. 811, 813 ;. (1932) 77 ibid. 781 ; see also Note (1912) 36 L. R. A. (x.s.) 1099. See Blodgett's Estate (1916) $254 \mathrm{~Pa}$. 
subject to depletion, the Act there adopts the orthodox rule that the returns from wasting assets are primcipal if the trustee is under a duty to convert, but where the trustee is under no duty to convert the returns are income. ${ }^{42}$ Section 9 abandons this test and lays down a rule apparently new, which applies only where "the trustee or tenant is authorized ... to sell, lease or otherwise develop such natural resources...." If these conditions exist-and no provision is made for cases where they do not exist-then the net proceeds, if received as rent on a lease, are income, but if received as consideration, whether as royalties or otherwise, for permanent severance, are principal. ${ }^{43}$ The form of the transaction seems to control. This emphasis on form seems unfortunate and to suggest ready means of circumvention.

The interest of a lessee under an oil lease, for example, where unlimited as to time, as such leases generally are, is in the nature of a profit a prendre and is a freehold interest. Whatever form the

210, 98 Atl. 876 (all royalties from coal lease made by donor go to legal life tenant). See also Ohio Oil Co. v. Daughetee (1909) 240 MI. 361, 88 N. E. 818, (1912) 36 L. R.A. (N.s.) 1108; Eager's Guardian v. Pollard (1922) $194 \mathrm{Ky} .276,239$ S. W. 39, (1926) 43 A. L. R. 808; Wentz's Appeal (1884) 106 Pa. St. 301; Bedford's Appeal (1889) 126 Pa.St. 117, 17 Atl. 538; 4 BOGERT, op. cit. supra note 7, \& 828; 2 PERRY, op. cit. supra note 19, § 547; Restateatent of the LAW of Trusts (Am. L. Inst. 1935) § 239. As to bonuses, see Herring v. Commissioner (1934) 293 U. S. 322.

42 UNIFORar ACT \& 10: "Principal subject to depletion. Where any part of the principal consists of property subject to depletion, such as leaseholds, patents, copyrights and royalty rights, and the trustee or tenant in possession is not under a duty to change the form of the investment of the principal, the full amount of rents, royalties or return from the property shall be income to the tenant; but where the trustee or tenant is under a duty, arising either by law or by the terms of the transaction by which the principal was established, to change the form of the investment, either at once or as soon as it may be done without loss, then the return from such property not in excess of five per centum per annum of its fair inventory value or in default thereof its market value at the time the principal was established, or at its cost where purchased later, shall be deemed income and the remainder principal."

48 UNIForar ACT \& 9: "Disposition of natural resources. Where any part of the principal consists of property in lands from which may be taken timher, minerals, oils, gas or other natural resources and the trustee or tenant is authorized by law or by the terms of the transaction by which the principal was estabbished to sell, lease or otherwise develop such natural resources, and no provision is made for the disposition of the net proceeds thereof after the payment of expenses and carrying charges on such property, such proceeds, if received as rent on a lease, shall be deemed income, but if received as consideration, whether as royalties or otherwise, for the pennanent severance of such natural resources from the lands, shall be deemed principal to be invested to produce income. Nothing in this section shall be construed to abrogate or extend any right which may otherwise have accrued hy law to a tenant to develop or work such natural resources for his own benefit."

44 Schiffman v. Richfield Oil Co. (1937) 8 Cal. (2d) 211, 64 P. (2d) 1081, Note (1938) 26 CALIF. L. Rev. 480; Notes (1936) 25 ibid. 220; (1936) 101 A. L. R. 884. 
transaction may take, and even though the consideration for the extraction of the mineral be camouflaged as rent under a lease, it would seem that in substance it represents compensation for removing a part of the land itself. It is believed, therefore, that section 9, insofar as it makes the rights of the parties depend upon the form of the transaction by which the natural resources are disposed of, states a rule somewhat unpredictable in operation.

Again, section 9 says that the rules stated apply where "the trustee or tenant is authorized ... to sell, lease or otherwise develop such natural resources." ${ }^{25}$ What bearing has an authority to sell upon the rule as stated in section 9? Where the result is dependent on an intended conversion, authority, as distinguished from a direction to sell, is relevant as partially negativing that intent. ${ }^{46}$ But in section '9, which makes no results dependent on conversion, the question of power of sale seems an irrelevant and alien element. If the resources are sold there would seem to be no difficulty in any case about giving the entire proceeds to principal. No new statute is needed to confer that authority. Furthermore, what is the meaning of the phrase, "to sell, lease, or otherwise develop"? ${ }^{47}$ To lease natural resources is a species of development, but to sell them is not.

The rule prescribed by section 9 seems lacking in clarity, and to make distinctions based on circumstances in part irrelevant, in part accidental. It is believed that section 9 should be recast to bring it into harmony with section 10 . With misgivings, the writer has attempted to restate the section, ${ }^{48}$ and in this revision has thought

45 Italics added.

46 See Note (1932) 77 A. L. R. 753, 774.

47 Italics added.

48 § 9. [Suggested revision]: (1) Where any part of the principal consists of property in lands from which may be taken timber, mineral, oils, gas or other natural resources, and the trustee or tenant in possession is not under a duty to change the form of the investment of the principal, or is authorized by law or by the terms of the transaction by which the principal was established, to lease or otherwise develop such natural resources, and no provision is made for the disposition of the net procecds thereof after the payment of expenses and carrying charges on such property, such proceeds shall be deemed income, whether received as rent or bonus on a lease as a consideration, by way of royalties, or otherwise for the permanent severance of such natural resources from the lands. A duty to change tbe form of the investment shall be negatived, and authority to develop such natural resources sball be deemed to exist (not excluding otber cases where appropriate intent is manifested) where (a) the resources or the right to exploit them is specifically devised or granted, or (b) where development or exploitation of the resources had begun prior to the transaction by which the principal was established, or (c) where by the terms of that transaction a general authority to lease or otherwise develop is conferred, or (d) where the lands 
it desirable to remove certain troublesome questions as to whether the duty to convert, or in certain cases the power to lease, exists, suggesting that authority to lease or otherwise develop exists (a) in case of specific grant or devise of the resources, or (b) where a general authority to lease is conferred, ${ }^{49}$ and in certain other cases. What the trustee may do to realize income in these instances is so closely allied to questions relating to disposition of imcome after the trust receives it, that the former seems an appropriate concern of a principal and income act, especially where that act makes certain provisions conditional upon the trustee being "authorized ... to lease or otherwise develop" natural resources. To tell the trustee what he may do with income from a certain source and fail to tell him whether the source is available seems rather futile. Granting that we are not dealing with a statute defining trustees' powers generally, it is never-

are directed to be retained. The fact that such property, where held in trust and received from the testator or settlor, does not fall within the category of investinents which the trustee would be authorized to make under the law or the terms of the particular trust, nor the conferring of a mere authority, as distinguished from a direction, to sell such property, shall not be deemed to evidence an intent that the form of the investment shall be changed. A general power to lease, unqualified as to time, shall be deemed as to lands containing natural resources to authorize leases outstaying the term of the trust or tenancy.

(2) Where any part of the principal consists of property in lands containing such natural resources, and the conditions under which the proceeds thereof become incoine shall not exist, then in the absence of the expression of contrary intent in the terms of the transaction by which the principal was established, all such proceeds from such resources, not im excess of ....... per centum per annum of the fair inventory value of such resources, or in default thereof their fair market value at the time the principal was established, or their cost if acquired later, shall be deemed income and the remainder principal.

(3) Nothing in this section shall be construed to abrogate or extend any right which may otherwise have accrued by law to a tenant to develop or work such natural resources for his own henefit.

Subsection (2) is intended to cover a gap in the present section 9 which leaves to inference what happens in case no authority is given to exploit the natural resources. In covering this gap, the theory of the revised, rather than the original, section 9 has obviously been followed.

49 Specific grant or devise: Union County Trust Co. v. Gray (1932) 110 N. J. Eq. 270, 159 Atl. 625, semble; Vaughan v. Buck (1841) 1 Phillips 75; Restatedrent of tFE LaW of Trusts (Am. L. Inst. 1935) § 239, comment e; see 2 JarMan on WIIIs (7th ed. 1930) 1211; see also authorities cited note 50, infra.

General authority to lease conferred: Stone v. Los Angeles (1931) 114 Cal. App. 192, 299 Pac. 838; Ohio Oil Co. v. Daughetee, supra note 41 (power to lease does not include power to lease for oil); 4 BOGERT, op. cit. stupra note 7, § 798; 2 PERRY, op. cit. supra note 19, § 528; cf. Wentz's Appeal supra note 41 (power to lease gives power to lease for coal mining; court points out lands worthless for anything else). 
theless true that the existence of the right to exploit natural resources is a matter which concerns life tenant and remainderman alone..$^{50}$

\section{VII}

Section 10. Principal subject to depletion. Section 10, as already noted, adopts the rule generally prevailing, under which the rights of life tenants and remaindermen in returns from wasting assets are made dependent upon the presence or absence of a duty to convert. ${ }^{51}$ It may be observed that the revision of section 9 suggested above is a less extreme application of this principle than is the case which section 10 illustrates. Where, for example, a leasehold, one of the items inentioned in section 10, is held in trust, the trust res disappears completely at its termination. If all the rents have been paid out to the life tenant there is nothing for the remainderman. ${ }^{62}$ On the other hand, in cases covered by section 9, e.g., timber lands, mines, quarries, the trust res is not entirely consumed by the exploitation of the natural resources which it contains but frequently has a substantial value in addition. Where, therefore, there is a willingness to give the life tenant the whole of the depleting asset in the absence of a direction to convert (section 10) it seems there should be no unwillingness to give him a part of the asset under the same conditions (section 9). In section 10, as in the preceding section, the writer has suggested incorporating certain clarifying provisions corresponding to those added to section 9.53

50 The above reasons seem to justify the inclusion in the draft of a provision relating to the duration of mineral leases which may be under a general power to lease. See South End Warehouse Co. v. Lavery (1910) 12 Cal. App. 449, 107 Pac. 1008 (lease void as to excess beyond trust term); Hunt v. Lawton (1926) 76 Cal. App. 655, 245 Pac. 803; Campbell v. Kawananakoa (1930) 31 Hawaii 500; 4 BOGERT, op. cit. supra note 7, § 787; 2 ' PeRRY, op. cit. supra note 19, § 484; Restateament of the Law of Trusts (Am. L. Inst. 1935) $\S 189$, comments c, d. For obvious reasons, exploiters of mineral lands will not accept leases himited as to time. Whether land shall come to remainderman free of, or encumbered with, a lease is a problem which, after all, concerns no one but the holders of successive estates in it.

51 For authorities re wasting assets, in addition to those cited in note 41 , supra, sce Sewell v. Sewell (1936) 363 Inl. 166, 1 N. E. (2d) 492; Industrial Trust Co. v. Parks (R. I. 1937) 190 Atl. 32, 109 A. L. R. 220, Note ibid. 234; Restatenrent of tHe LAw of Trosts (Am. L. Inst. 1935) \& 236, comment z; Barry, Wasting Assels and Amortization (1935) 21 VA. L. REv. 611.

52 Industrial Trust Co. v. Parks, supra note 51, illustrates the principle.

$53 \S 10$ [Suggested revision]: Where any part of the principal consists of property subject to depletion, including leaseholds, patents, copyrights, royalty rights and stock in corporations engaged in the exploitation of timber, minerals, oils, gas or other wasting assets, and the trustee or tenant in possession is not under a duty to change the 
Accepting the principle of section 10, there seems to be one important case not covered by it, nor plainly coming within any other provision of the Act. That is the case of wasting asset corporations. ${ }^{54}$

The doctrine of Knox's Estate, ${ }^{55}$ in effect ignoring the corporation where it is interposed between the trust and the wasting assets, and treating the dividends as though they came directly from those assets, seems equitable and likely to be in accordance with the intent of most settlors having similar securities. That rule has the further merit, by no means inconsiderable, of avoiding the necessity of determining what are wasting asset corporations. Are, for example, Kelmecott Copper, or the various Standard Oil Companies? To expect a trustee holding a relatively few shares to answer such questions, though, flattering in its attribution of omniscience, is impractical, and is disturbing to the trustee, who construes it as an invitation to make perilous decisions. The test of whether the corporation regards the value of its properties as diminishing through exploitation should meet all reasonable requirements. ${ }^{56}$

A suggested revision of section 10, incorporating the $K n o x$ case doctrine, is presented in the footnotes. ${ }^{57}$

form of the investment of the principal, the full amount of rents, royalties, dividends or other returns from the property shall be income to the tenant; but where the trustee or tenant is under a duty [etc.].

Add: A duty to change the form of the investment shall be negatived (not excluding other cases where appropriate intent is manifested) (a) where such property is specifically devised, bequeathed, or granted; or (b) where such property is directed to be retained. The fact that such property, where held in trust and received from the testator or settlor does not fall within the category of investments which the trustee would be authorized to make under the law or the terms of the particular trust, nor the conferring of a mere authority, as distinguished from a direction, to sell such property, shall not be deemed to evidence an intent that the form of the investment shall be changed.

54 Washington County Hospital Ass'n v. Hagerstown Trust Co. (1914) $124 \mathrm{Md}$. 1, 91 Atl. 787; Creed v. McAleer, supra note 30; De Brabant v. Commercial Trust Co.' (1933) 113 N. J. Eq. 215, 166 Atl. 533, Note (1934) 43 YaLE L. J. 1336; Waterman's Estate (1924) $279 \mathrm{~Pa}$. 491, 124 Atl. 166; Knox's Estate (1937) $328 \mathrm{~Pa}$. 177, 195 Atl. 28, (1938) 113 A.L. R. 1185, (1938) 51 HARv. L. REv. 936; 4 BOGERT, op. cit. supra note 7, § 828; Note (1938) 113 A.L. R. 1193. See Restatement of tere LaW of TrUSts (Am. L. Inst. 1935) § 236, comment $z$. The Restatement in requiring the trustee to determine the extent to which dividends encroach on corporate assets is believed to state an inpractical rule.

55 Supra note 54. The same reasoning is applied in Cadbury v. Parrish (N. H. 1938) 200 Atl. 791.

56 This rule was applied in City Bank Farmers Trust Co. v. McCarter (1932) 111 N. J. Eq. 315, 162 Atl. 274.

57 See note 53, supra. 


\section{VIII}

Section 11. Unproductive estate. Although section $11^{68}$ has met with opposition on various fronts, ${ }^{59}$ it seems to the writer a satisfactory solution of a vexing problem. Relieving the life tenant, after one year, of the burden of carrying charges on unproductive property and giving him a share in its proceeds when conversion is delayed beyond that period seem equitable in view of the fact that deferinent of sale is generally for the assumed benefit of principal. Provisions of this kind, either in the governing law or in the particular trusts concerned, would have relieved many distressing situations during the depression. That the section embodies no experiment is

58 UNIFORM ACT \$ 11: "Unproductive estate. (1) Where any part of a principal in the possession of a trustee consists of realty or personalty which for more than a year and until disposed of as hereinafter stated has not produced an average net income of at least one per centum per annum of its fair inventory value or in default thercof its market value at the time the principal was established or of its cost where purchased later, and the trustce is under a duty to change the form of the investment as soon as it may he done without sacrifice of value and such change is delayed, but is made before the principal is finally distributed, then the tenant, or in case of his death his personal representative, shall be entitled to share in the net proceeds received from the property as delayed income to the extent bereinafter stated.

"(2) Such income shall be the difference between the net proceeds received from the property and the amount which, had it been placed at simple interest at the rate of five per centum per annum for the period during which the change was delayed, would have produced the net proceeds at the time of change, but in no event shall such income be more than the amount by which the net procceds exceed the fair imventory value of the property or in default thereof its market value at the time the principal was established or its cost where purchased later. The nct proceeds shall consist of the gross proceeds received from the property less any expenses incurred in disposing of it less all carrying charges which have been paid out of principal during the period while it has been unproductive.

"(3) The change shall be taken to have been delayed from the time when the duty to make it first arose, which shall be presumed, in the absence of evidence to the contrary, to be one year after the trustee first reccived the property if then unproductive, otherwise one year after it became unproductive.

"(4) If the tenant has received any income from the property or has had any beneficial use thereof during the period while the change has been delayed, his share of the delayed income shall be reduced by the amount of such income received or the value of the use had.

"(5) In the case of successive tenants the delaycd income shall be divided among them or their representatives according to the length of the period for which each was entitled to income."

50 See Uniform Principal and Income Act (1937) 64 Trust CoMrpanIEs 765 (report says section 11 "arbitrary"). It was omitted from a draft of a principal and income act approved for submission to the legislature by the California Bankers Association in November, 1938. 
attested by the successful operation in New York of the principle which it substantially codifies. ${ }^{\text {BO }}$

\section{IX}

Disposition of proceeds of defaulted interest-bearing obligations. Following section 11 is an appropriate place to discuss this subject, which is not covered by the Act except to the extent that section 11 may cover it partially and by inference. Since most of the cases involve foreclosed mortgages, the discussion will deal first, and mainly, with that phase of the topic.

Property acquired on foreclosure. ${ }^{61}$ The disposition as between life tenant and remamderman of property taken on foreclosure has assumed great importance since 1931. In a discussion of a principal and income act it seems appropriate to deal with this problem in specific terms.

What has come to be known as the apportionment rule applies in such cases. Briefly stated, this rule is that when a trustee forecloses a mortgage or takes over the mortgage security without foreclosure, and subsequently sells it, failing to realize the full amount of the debt, principal and mcome share the loss ratably. On one side, the trustee puts his original investment, advances for taxes, expenses, repairs,

${ }^{60}$ See Lawrence v. Littlefield; Furniss v. Cruikshank, both supra note 7; see also Matter of Jackson (1932) 258 N. Y. 281, 179 N. E. 496; Matter of Satterwhite (1933) 262 N. Y. 339, 186 N. E. 857 ; Matter of Rowland (1937) 273 N. Y. 100, 6 N. E. (2d) 393 (mandatory direction to convert presumed under certain conditions); Matter of Wainwright (1936) 248 App. Div. 336, 289 N. Y. Supp. 510; Matter of Clarke (1938) 166 Misc. 807,3 N. Y. S. (2d) 60 (unproductive personalty, paintings).

Generally on unproductive property and duty to convert, see: Love v. Engelke (1938) 368 III. 342,14 N. E. (2d) 228 (no apportionment unless imperative duty to convert); Rhode Island Hospital Trust Co. v. Tucker (1932) 52 R. I. 277, 160 Atl. 465 (stock producing only stock dividends); 4 BoGERT, op. cit. supra note $7, \S \S 804,826,827$; Carey and Moodie, Unproductive Property in Trust Accounting (1938) 33 Inc. L. REv. 398; Notes (1935) 35 Cot. L. REv. 306; (1937) 5 U. of CrI. L. REv. 122; (1930) 40 YAIE L. J. 275.

${ }^{61}$ Section 241, comment b, of the Restatement of Trusts (Am. L. Inst. 1935) makes applicable to mortgages on which there is a default in payment of interest, rules substantially the same as those prescribed in section 11. This fits some cases, not all, as frequently the mortgage (or the property received in its place) produces a substantial and uninterrupted income, but nevertheless, a loss is realized on liquidation. On principle, it seems to be indulging a fiction too far to say that a trustee is "under a duty to sell" a defaulted inortgage. Notoriously, it cannot be done except on terms ruinous to income and principal alike.

What would a trustee acting under the Uniform Act do in this contingency? Would the real property be regarded simply as a substituted asset, and all the loss fall on principal? (It is to be remembered that principal and incoune rely upon the 
etc., crediting against these items all rents from the property. On the other side will be accrued and unpaid interest. When the trustee sells the property, advances will be repaid insofar as rentals have been insufficient to pay them and the balance apportioned between principal and incoine. ${ }^{62}$

In applying this rule numerous questions, not answered in the Uniform Act and not fully answered in any jurisdiction, arise suggesting the desirability, almost the necessity, of a special section dealing exclusively with these obligations. Among them are the following:

(a) Interest after default. Is interest to be computed at the mortgage rate or at the current rate on trust investments? If the latter, as of what date does the trustee begin using the new (and under present circumstances, lower) rate? Does it run from date of default in payment of interest or from date of foreclosure by the trustee?

In New York the unortgage rate governs; ${ }^{63}$ in Pennsylvania the current rate on trust investments. ${ }^{64}$ The writer, in drafting a section covering the apportionment rule ${ }^{65}$ has adopted the mortgage rate. ${ }^{66}$

same promise and security. Why favor one at the other's expense?) How would this loss be determined? Would the cost to principal include advances for delinquent taxes and assessments, attorney's fees, repairs required to render the property tenantable, etc.? To what extent would these items be chargeable against income? The Act seems to afford no clear solution to these problems. Matter of Chapal (1936) 269 N. Y. 464, 199 N. E. 762 , 103 A. L. R. 1268 , seems to recognize the inapplicability of the unproductive property rules to this class of cases. Those rules, though familiar to the courts; have not heen applied in any of the numerous cases dealing with this problem. Sec note 62 , infro.

62 Equitable Trust Co. v. Swoboda (1933) 113 N. J. Eq. 399, 167 Atl. 525; Hudson County Nat. Bank v. Woodruff (1937) 122 N. J. Eq. 444, 194 Atl. 266, mod. and aff'd, (1938) 123 N. J. Eq. 585, 199 Atl. 399; Matter of Chapal, supra note 61; Matter of Otis (1937) 276 N. Y. 101, 11 N. E. (2d) 556, (1938) 115 A. L. R. 875, rearg. den., (1938) 14 N. E. (2d) 203; Nirdlinger's Estate, supra notes 23, 7; 4 BOGERT, op. cil. supra note $7, \$ 820$; 65 C. J. 822 ; 2 PERRY, op. cit. supra note 19, § 548 (c); Note (1938) 116 A. L. R. 1354 , on allocation between principal and income of amount reccived on disposition or liquidation of defaulted securities.

63 Matter of Otis, supra note 62.

64 Nirdlinger's Estate, supra notes 23, 7. See also Restatement of THE LAW of Trusts (Am. L. Inst. 1935) § 241, comment d.

$65 \mathrm{New} \S 11$ (a): Disposition of proceeds of defaulted interest bearing obligations. (1) Whenever a trustee holding an obligation for the payment of money secured by unortgage or other voluntarily created lien upon real or personal property shall forcclose such lien or acquire the property securcd thereby in heu of foreclosure and shall thereafter dispose of such property for a sum insufficient to pay the full amount of the trustec's mvestment therein, together with interest. on the mortgage at the contract rate, the following rules shall govern the disposition of the proceeds received upon such salc. 
(b) Disposition of rents pending liquidation. In the absence of statute the trustee cannot with entire safety apply rents from the property to the payment of income to the life tenant, since the amount of these payments may exceed the mcome which the life tenant is

The trustee's investment in such property shall be deemed to include the unpaid principal, together with all advances (to be paid out of principal) for taxes, assessments, costs of foreclosure, carrying charges, repairs and other expenses incurred in connection with the protection of the security or the acquisition, care and preservation of the property, less any rentals received from the property, and less any sums, principal or interest, received or collected from persons liable for the payment of such debt. When the trustee shall sell such property all advances for the purposes aforesaid shall be first repaid and the remaining proceeds shall be apportioned between principal and incoine in the proportion which the investment therein then remaining unpaid bears to the interest then accumulated upon the mortgage indebtedness, excluding advances, computed at the contract rate. If cash received upon such sale shall, after repayment of advances, be insufficient to pay the income then due, computed as aforesaid, subsequent payments on account of the principal of the purchase price shall be first applied to payment of such accrued income, and thereafter shall be applied upon principal. The trustee may pay to the tenant, after advances have heen repaid, any net rents over and above the carrying charges on the property, and such payments shall be a credit upon sums ultimately payable to the tenant upon liquidation. If found to exceed that sum, the trustee shall reimburse principal to the extent of such excess, out of other income, if any, otherwise payable to the tenant during the continuance of the tenancy, but the trustee shall have no further responsibility as to the repayment of such excess. If such property shall be sold by the trustee at a price in excess of the investinent therein, such profit, after payment to the tenant of all sums due him as interest, shall go to principal. If the tenant's right to income shall cease and determine by death or in any other manner prior to final settlement with him under the foregoing provisions, he or his personal representative shall be entitled only to such sums upon account of income accrued prior to the termination of his tenancy as may be received by the trustee within one year after his right to income shall cease, and any remaining incoine accrued prior to the time last mentioned and thereafter collected shall be paid to the person next entitled to incoine hy the terms of the transaction by which the principal was established.

(2) Upon the sale, surrender or other disposition of a bond, debenture, note or mortgage or other evidence of an indebtedness, voluntarily created, or of a certificate of deposit evidencing the deposit of any such instrument with a protective or reorganization cominittee, or of stock or other security received through participation in the enforcement of such obligation or the foreclosure of the security therefor, upon which bond or other obligation there is overdue unpaid interest which accrued during the existence of the trust, the proceeds realized upon such sale, surrender or other disposition, after repayment (1) of expenses incurred in connection therewith, and (2) of any sums paid to protect or preserve such security, shall be divided pro rata between income and principal, computing interest at the rate specified in such obligation. The anount allocable to income shall in no case exceed the interest accrued and unpaid on the original obligation up to the time of such sale or other disposition; or, where another security has been received in lieu of the original obligation, the income which would have accrued on the latter up to such time, less income received from the original or the substituted security. The terms sale, surrender or other disposition, as above used, shall include compromise, settlement, accord and satisfaction, and similar arrangennents.

66 If the rate is reduced the life tenant is being penalized twice, first by reduction of the rate, and second by further discount even from the reduced rate, where the prop- 
ultimately entitled to receive. ${ }^{67}$ The rule of the $\mathrm{Otis}^{68}$ and $\mathrm{Nirdlinger}^{60}$ cases, permitting discretionary payment of rents to the life tenant pending liquidation, seems practical and has been adopted in the proposed section.

(c) Should interest be paid on advances? The Otis case says "No"; the Nirdlinger case, "Yes." "To The noes seem to have it, though the contrary arguments are not negligible.

(d) Should sums due income account be paid first where property is not sold all for cash? The answer to this important practical problem seems to be "Yes." This view is supported by the Nirdlinger case, ${ }^{71}$ with the Otis case opposed.

(e) Should there be a time limit beyond which accruals on obligations in default before a life tenant's death should not be paid to his estate? Fully coguizant of its departure from a pattern of abstract justice, but believing it to be sensible, the writer has adopted the rule of In re Spear's Estate, ${ }^{72}$ adding, for practical reasons, an arbitrary time limit of one year.

(f) Apportionment of gains. Should the life tenant participate in gains where the property is sold at a profit? The majority say "No."73 This rule seems consistent with the generally accepted

erty is sold at a loss. It seems equitable that each claimant should suffer the same proportionate deduction. On the practical side, there is uncertaiuty as to the current rate. If the current return theory is to be adopted it would seem better to provide for an arbitrary rate-say four per cent, but in no event in excess of the mortgage rate.

67 Trenton Trust \& Safe Deposit Co. v. Donnelly (1903) 65 N. J. Eq. 119, 55 Atl. 92, arguendo (life tenant not entitled to income from real estate as such). Matter of Otis, supra note 62 , holds that the trustee has discretion, at least under certain circumstances, to distribute as income surplus net rents after repayment of principal advances. See Nirdlinger's Estate, supra notes 23, 7. Accord: Crimmin's Estate (1936) 159 Misc. 499, 288 N. Y. Supp. 552 ; Matter of Brainerd (1938) 169 Misc. 640,8 N. Y. S. (2d) 413 (poiuts out danger of possible surcharge of trustee through too hberal exercise of this power). See Restatement of the Law of Trusts (Am. L. Inst. 1935) § 241, comments b, d. The writer's draft of the new section proposes an intended practical solution.

68 Supra note 62.

${ }^{69}$ Supra note 7.

70 Supra note 23 , at 175,193 Atl. at 32 . At current rate.

$\pi$ Ibid.

72 Supra note 24.

73 Parker v. Johnson (1883) 37 N. J. Eq. 366; but see Parker v. Seeley (1897) 56 N. J. Eq. 110, 38 Atl. 280; Skinner v. Boyd (1925) 98 N. J. Eq. 55, 130 Atl. 22 ; see Neal's Estate (1904) 207 Pa. 446, 56 Atl. 950; Slocum v. Ames (1896) 19 R. I. 401,36 Atl. 1127; see also Estate of Gartenlaub, supra note 37; Estate of Canfield (1930) 104 Cal. App. 181, 285 Pac. 363 ; cf. Park's Estate (1896) 173 Pa. 190, 33 Atl. 884 (where life tenant to get "income and profits," entitled to profits realized on sale). 
doctrine that gains on trust assets go to principal, not income. Income from this source is not conteinplated in making investments. When it arises it should be used to counterbalance losses.

(g) Mortgages taken on sale of trust real estate. Should the apportionment rule apply to mortgages taken by a trustee on sale of land as to which it has a mere power, not the obligation, to sell, and where the terms of the trust are such that the trustee would have been authorized to retain the lands? The New Jersey court answers this question in the negative. ${ }^{74}$

Although there is a logical basis for this distinction, practically it seems desirable to sacrifice logic to uniformity, and to apportion in all cases.

Defaulted securities other than mortgages. (a) It seens clear that where, for example, a bond issue is foreclosed and the trustee receives either (1) a proportionate share of cash realized upon the foreclosure, or (2) stocks or other securities as a result of participation in a reorganization, the cash in the one case or the proceeds of stock or other securities in the other, when sold, should be apportioned upon the same basis as proceeds received in liquidation of mortgages. ${ }^{75}$ (b) Aside from this situation there are others less easy of solution. Suppose (1) a sale or other disposal by a trustee of defaulted interestbearing obligations, and (2) a sale or other disposal by a trustee of non-interest-bearing obligations-stocks, etc.

Entitled to participate: Parker v. Seeley; Skinner v. Boyd, both supra; cf. Burnett v. Witschief (1924) 96 N. J. Eq. 71, 126 Atl. 23 (no right to profit realized on resale, after foreclosure of purchase money mortgage, of lands sold by trustees pursuant to power, not mandatory direction).

74 See Burnett v. Witschief, supra note 73 (property is real estate, not personalty, in hands of trustee; no duty to convert; hife tenant entitled to income from property as real estate). And see Fidelity Union Trust Co. v. Murphy (N. J. Ch. 1938) I A. (2d) 201.

75 Quinn v. First Nat. Bank (1934) 168 Tenn. 30, 73 S.W. (2d) 692; Londesborough v. Sonierville (1854) 19 Beav. 295. Proceeds realized on liquidation of certificates of investnient in real estate pool apportioned. In re Atkinson [1904] 2 Ch. 160; see Note (1936) 103 A. L. R. 1271, 1286. And see Hubbard v. Fubbard (1937) 172 Md. 645, 647, 192 Atl. 592, 594 (notes secured by pledge of same debtor's mortgage bonds).

In re Taylor's Trusts [1905] $1 \mathrm{Ch}$. 734, suggests apportionment is limited to cases where obligation to pay interest absolute; not applied to proceeds of sale of bonds where interest payable only out of earnings.

The New York court in the Otis case, supra note 62, refused to apply the apportionment rule to a case where a defaulted mortgage was exchanged for Home Owners Loan Corporation bonds. To apply to such a transaction, as the court does, rules applicable to free sales or exchanges seems to ignore realities. 
(1) Sale of interest-bearing obligations. Under some of the authorities an apportionment will be made. ${ }^{76}$ This seems correct. Apportionment should not depend on the somewhat accidental choice -outright sale or "workout" througl more gradual liquidationwhich the trustee adopts.

(2) Non-interest-bearing securities-stocks, etc. Probably the apportionment rule should not be extended to this class of cases. ${ }^{77}$ If there is any apportionment in such cases it would seem properly to come within the provisions of section 11 , relative to unproductive estate, rather than within rules which seem more properly applicable, and to be limited to, interest-bearing obligations. In the latter case there is a definitely ascertainable amount, unconditionally a liability of the promisor, of equal dignity with the promisor's agreement to pay the principal. These similar obligations should receive like treatment. Manifestly, a qualified obligation, such as a dividend on preferred stock, stands on a different footing.

Should the apportionment rule be abolished? This further inquiry seems necessary because of a certain amount of opposition to the rule. ${ }^{78}$ The objections are practical and are based primarily upon convenience. If the apportionnent rule were abolished, real estate coming into the trust upon foreclosure would be simply a substituted asset, the net income, if any, from which would go to the life tenant pending disposal. What provision would be made concerning income to the life tenant from date of default to the time when the trustee becomes entitled to the rents-in some cases a long time-is not altogether clear.

76 See note 75 , supra.

77 Matter of Otis, supra note 62 (the rule of that case would apply a fortiori here); Southern Ohio Sav. Bank \& Trust Co. v. Hayward, supra note 28 (cash and securities received by a trustee in exchange for preferred stock in recapitalization of Otis Steel Counpany; apportionment rule not applied to stocks received but all went to corpus); In re Taylor's Trusts, supro note 75.

In Matter of Lander (1937) 162 Misc. 201, 294 N.Y. Supp. 58, apportionment was denied upon sale of preferred stock upon which accumulated dividends remained unpaid.

See Notes (1936) 103 A. X. R. 1286, 1299; (1938) 115 ibid. 889. In Pennsylvania an apportionment between principal and income is allowed on sale of stocks where the sales price reflects earnings after inception of the trust. Nirdhinger's Estate (1927) 290 Pa. 457, 139 Atl. 200, (1928) 56 A. L. R. 1303; Daily's Estate (1936) 323 Pa. 42, 46, 186 Atl. 754, 756.

78 A plebiscite taken in 1939 among trust companies doing business in California disclosed a majority in favor of abolishing the apportionment rule. For a recent statute to that effect see Conn. Laws 1939, c. 232. Insofar as objections on practical grounds are well-founded, it is believed they would be obviated by the various clarifying provtsions above suggested. 
Where the property is unproductive it would seem that it should come within the rules applicable to the non-productive property generally (section 11 if that section is adopted) and that within those limits there should be an apportionment upon sale. It has already been pointed out that section 11 is soinewhat general in its terms so far as this specific issue is concerned; and further, there are potentialities of confusion in requirmg or not requiring apportionment, depending on the productiveness of the property. And agam, what would the abolitionists suggest in case of defaulted bonds, the security for which is foreclosed and something else, frequently after a long interval, received, or in the case of defaulted unsecured notes and debentures? It seems questionable whether the proposed solution is as simple as it sounds, and whether its adoption would not result in patchwork, defeating to that extent the objectives of consistency and simplicity toward which the Act should be directed. That the abolition of the rule would work to the disadvantage of life tenants in the vast majority of cases seems manifest.

\section{$\mathrm{X}$}

Section 12. Expenses-trust estates. ${ }^{79}$ (a) Trustee's fees. In subsections (1) and (2) the trustee's "commissions computed on

79 UNIFORM ACT § 12: "Expenses-trust estates. (1) All ordinary expenses incurred in connection with the trust estate or with its administration and management, including regularly recurring taxes assessed against any portion of the principal, water rates, premiums on insurance taken upon the estates of both tenant and remainderman, interest on mortgages on the principal, ordinary repairs, trustees' compensation except commissions computed on principal, compensation of assistants, and court costs and attorneys' and other fees on regular accountings, shall be paid out of income. But such expenses where incurred in disposing of, or as carrying charges on, unproductive estate as defined in section 11 , shall be paid out of principal, subject to the provisions of subsection (2) of section 11 .

"(2) All other expenses, imcluding trustee's commissions computed upon principal, cost of investing or remvesting principal, attorneys' fees and other costs incurred in maintaining or defending any action to protect the trust or the property or assure the title thereof, unless due to the fauit or cause of the tenant, and costs of, or assessments for, improvements to property forming part of the principal, shall be paid out of principal. Any tax levied by any authority, federal, state or foreign, upon profit or gain defined as principal under the terms of subsection (2) of section 3 shall be paid out of principal, notwithstanding said $\operatorname{tax}$ may be denominated a $\operatorname{tax}$ upon income by the taxing authority.

"(3) Expenses paid out of income according to subsection (1) which represent regularly recurring charges shall be considered to have accrued from day to day, and shall be apportioned on that basis whenever the right of the tenant begins or ends at some date other than the payment date of the expenses. Where the expenses to be paid out of income are of unusual amount, the trustee may distribute them throughout an 
principal" are made a corpus charge. This may lead to some confusion because of the fact that increasingly throughout the country, the current compensation of trustees is computed, in part at least, on principal..$^{80}$ It would seem that the test should be not whether the trustee's compensation is computed on principal or income, but on whether it is paid for current or recurring services, on the one hand, or for extraordinary or non-recurring services beneficial wholly or mainly to the remainderman, on the other. If the former, it should be deducted from incoine; if the latter, from corpus. ${ }^{81}$

(b) Subsection (4). Improvements. Subsection (4) of the Uniform Act, in requiring amortization out of income of the cost of an improvement based upon its reasonably expected duration, has been criticized because of the burden it puts on trustees to determine this

entire year or part thereof, or throughout a series of years. After such distribution, where the right of the tenant ends during the period, the expenses shall be apportioned between tenant and remainderinan on the basis of such distribution.

"(4) Where the costs of, or special taxes or assessments for, an improvement representing an addition of value to property held hy the trustee as part of principal are paid out of principal, as provided in subsection (2), the trustee shall reserve out of income and add to the principal each year a sum equal to the cost of the improvement divided by the number of years of the reasonably expected duration of the improvement."

Expenses: Bridgeport-City Trust Co. v. First Nat. Bank \& Trust Co. (1938) 124 Conn. 472, 200 Atl. 809, (1938) 117 A. L. R. 1148, 1154 (trustee's fees); Creed v. McAleer, supra note 30 (compensation for trustec's services rendered after life tenant's death paid from corpus); Kingsley v. Spofford (Mass. 1937) 11 N. E. (2d) 487 (insurance); Butler v. Builders Trust Co. (1938) 203 Minn. 555, 282 N. W. 462 (trustee's bond); In re Levy's Estate (Pa. 1939) 5 A. (2d) 98 (court's discretion as to carrying charges on unproductive realty); McDavid v. McDavid (1938) 187 S. C. 127, 197 S. E. 204 (taxes on unproductive property paid from corpus).

Taxes on capital gains: Holcombe v. Ginn (Mass. 1937) 6 N. E. (2d) 351, 108 A. L. R. 1134 ; Industrial Trust Co. v. Winslow (R. I. 1938) 197 Atl. 185 ; cf. Evans v. Ockershausen (App. D. C. 1938) 100 F. (2d) 695.

Apportionment of taxes: Safe Deposit \& Trust Co. of Baltimore v. White (C. C. Baltimore, 1939) 68 Trusis \& EstatzS 140. The cases are conflicting. See Note (1935) 44 YaLE L. J. 1110.

Improvements: Hill v. Fill (1932) 61 App. D. C. 72, 57 F. (2d) 438 (cost of installing electric refrigerators in apartment house charged to corpus, not reimbursed from income); Evans v. Ockershausen, supra.

${ }^{80} \mathrm{~A}$ schedule of fees, published in 1939 by Trust Division, American Bankers Association, New York City, shows that the principal basis for current fees is used, wbolly or partly, by corporate fiduciaries in twenty-five states.

81 Estate of Kruce (1935) 10 Cal. App. (2d) 426, 51 P. (2d) 1174; 4 BogerT, op. cil. supra note 7, § 805; RestaTEMENT of THE LAw of TRUSTs (Am. L. Inst. 1935) § 233, comments $e, f, h$. There should be noted here a feeling, not universal but conmon, ainong professional trustees that the traditional method of deducting the trustee's compensation from income is not entirely equitable. For a recently enacted statute unaking part of the trustee's ordinary compensation a principal charge, see Code of Pub. Gen. Laws of Md. 1939, art. 16, § 268B. 
factor. ${ }^{82}$ Manifestly, the determination nivites sone risk. The tendency in such cases to discriminate against life tenants has already been noted. Theoretically, the amortization rule proposed in subsection (4) seems to be the nost equitable of any. ${ }^{83}$

Is it the nuost practical? Plainly there are cases to which it does not apply. For example, suppose the street grade is changed. Whether an improvement or not, it is permanent. On the other hand, a pavement is not permanent. But when we come to estimating how long it will last, the guesses, even of experts, will differ widely. Nothing, of course, is permanent in the absolute sense, but exceedingly difficult problems arise as to what is permanent, even relatively. Is a sewer permanent? Or a retaining wall? Or a sidewalk? Bearing in mind practical considerations, it seems better to adopt an arbitrary rule which will approximate justice in most instances by providing that the expense of all improvements, not coming within the category of ordinary repairs, which represent an addition of value to property, shall be charged to corpus, and interest on the cost charged to income during the continuance of the particular estate, the total interest contributions not to exceed the cost of the improvement. This method, applying irrespective of so-called permanence the doctrine of Plympton v. Boston Dispensary, ${ }^{84}$ eliminates the element of prophecy and has the further merit of simplicity. If the particular estate ends quickly, the accumulated interest plus the enhanced value of the principal will compensate the latter for its expenditure; if it continues a long time, the diminishing accretion to principal value will be substantially offset by interest accumulations. In those few cases where the improvement is of short duration and the liability for interest outlasts the improvement itself, there will be no substantial injustice in requirmg the life tenant to pay for an improve-

82 See Proceedings, California Bankers Association (1938) 102.

83 Troy v. Protestant Episcopal Church (1911) 174 Ala. 380, 56 So. 982, (1914) 32 Ann. Cas. 815 (legal life estate); Sheffield v. Cooke (1916) 39 R. I. 217, 98 Atl. 161, Ann. Cas. 1918E 961; see 4 BOGERT, op. cit. supra note 7, § 803; 2 PERRY, op. cit. supra note 19 , $\$ 554$; Restatement of tHe Law of Trusts (Am. L. Inst. 1935) $\S 233$, comments $j, k, l$.

84 (1871) 106 Mass. 544 (expense of improvement treated as an encumbrance on estate; life tenant must pay interest during his life, remainderman the principal; share this expense in same proportion they would have benefited if damages had been awarded in favor of the estate; theory is that remainderman has improved the property for life tenant's benefit) ; see also Cooper v. Barton (1929) 208 Iowa 447, 226 N. W. 70; Chamberlin v. Gleason (1900) 163 N. Y. 214, 57 N. E. 487 (pavement; interest on installments as they accrue; question of payment of interest during life tenant's life not regarded as important under facts). 
ment of which he alone receives the benefit. If his estate outlasts the improvement, but ends before interest payments have reimbursed principal, the slight detriment the remainderman will suffer may well be ignored. Such instances will be rare and the cost of the improvement in those cases is apt to be relatively small. If the property is sold - a point which the Umiform Act does not cover-a balance may be struck between principal and income at that time. Its theoretically enhanced selling price may be deemed to complete the reimbursement to principal.

A revision of subsections (1), (2), and (4) of section 12 designed to carry into effect the substance of the foregoing is suggested for consideration..$^{85}$

$85 \& 12$ [Suggested revision]: (1) All ordinary expenses incurred in connection with the trust estate or with its administration and management, including regularly recurring taxes assessed against any portion of the principal, water rates, premiums on insurance taken upon the estates of hoth tenant and remainderman, interest on mortgages on the principal, ordinary repairs, trustees' compensation for ordimary current services, commissions and expenses paid for negotiating or effecting leases for terms not longer than five years, compensation of assistants, and court costs and attorneys' and other fees on regular accountings, shall be paid out of income. But such expenses [continue as at present].

(2) All other expenses, including trustees' compensation upon acceptance or distribution of principal, and for extraordinary or non-recurring services beneficial wholly or mainly to principal, the cost of investing or reinvesting principal, commissions and expenses on sales, purchases and exchanges of trust property and for negotiating or effecting leases for terms longer than five years, attorneys' fees and other costs incurred in maintaining or defending any action to protect the trust or the property or assure the title there of, unless due to the fault or eause of the tenant, and costs of, or assessments for, improvements to property forming part of the principal, shall be paid out of principal. Commissions and expenses incurred in connection with leases for terms longer than five years shall be charged to principal in the first instance, and a part thereof, proportionate to the number of years of the term, shall be repaid from income to principal in each year while the lease and the trust shall co-exist. Any tax levied by any authority [continue as at present].

(4) Where the costs of, or special taxes or assessments for, an improvement representing an addition of value to property held by the trustee as part of principal are paid out of principal, as provided in subsection (2), the trustee shall reserve out of income and add to the principal each year a sum equal to interest computed at ........ per centum per annum on the cost of the improvement, the total of such contrihutions not to exceed the cost of the improvement. The duty to make such contributions shall cease upon sale or other disposal of the property by the trustee.

The provisions as to brokers' cominissions are adapted from Mass. ANN. Laws (Michie, 1932) c. 203, \& 22, as amended 1938 Cum. Supp. c. 203, \& 22. As to cominissions generally, see Hite's Devisees v. Hite's Executors (1892) $93 \mathrm{Ky.} \mathrm{257,} 20 \mathrm{~S}$. W. 778, (1893) 19 L. R.A. 173 (commissions apportioned); Heard v. Eldredge (1872) 109 Mass. 258, (1874) 12 Am. Rep. 687 (commissions charged to income) ; Jordan v. Jordan (1906) 192 Mass. 337, 78 N. E. 459 (same rule followed but court expresses dissatisfaction); Whittemore v. Beekman (Surr. Ct. N.Y. 1883) 2 Dem. 275 (charged to 


\section{XI}

Sections 13 to 16 , inclusive, not commented on here, are reprinted below. ${ }^{86}$

Section $17,{ }^{87}$ relating to the time when the Act takes effect, may be given some attention since the practical usefulness of the Act will be vastly increased by making it applicable to existing trusts insofar as that objective may be attained without disturbing vested rights. Assuming that the Act cannot affect rights irrevocably conferred prior to its effective date, ${ }^{88}$ it is believed that it can constitutionally be made effective as to all pre-existing revocable trusts, or those

corpus) ; Rhode Island Hospital Trust Co. v. Waterman (1901) 23 R. I. 342, 50 Atl. 389 (commissions apportioned). See generally 65 C. J. 824; 4 BOGERT, op. cit. supra note 7, \$ 805; 2 PERRX, op. cit. supra note 19, \$ 554.

86 UNIFORM ACT $\$ 13:$ : "Expenses-non-trust estates. (1) The provisions of section 12, so far as applicable and excepting those dealing with costs of, or special taxes or assessments for, improvements to property, shall govern the apportionment of expenses between tenants and remaindermen where no trust has been created, subject, however, to any legal agreement of the parties or any specific direction of the taxing or other statutes; but where either tenant or remainderman has incurred an expense for the benefit of his own estate and without the consent or agreement of the other, he shall pay such expense in full.

"(2) Subject to the exceptions stated in subsection (1) the cost of, or special taxes or assessments for, an improvement representing an addition of value to property forming part of the principal shall be paid by the tenant, where such improvement cannot reasonably be expected to outlast the estate of the tenant. In all other cases a portion thereof only shall be paid by the tenant, while the remainder shall be paid by the remainderman. Such portion shall be ascertained by taking that percentage of the total which is found by dividing the present value of the tenant's estate by the present value of an estate of the same form as that of the tenant except that it is limited for a period corresponding to the reasonably expected duration of the improvement. The computation of present values of the estates shall be made on the expectancy basis set forth in the American Experience Tables of Mortahity and no other evidence of duration or expectancy shall be considered."

UNIFORA ACT § 14: "Uniformity of interpretation. This act shall be so interpreted and construed as to effectuate its general purpose to make uniform the law of those states which enact it."

UNIFORM ACT §15: "Short title. This act may be cited as the Uniform Principal and Income Act."

UNIFORM ACT $\S 16$ : "Repeal. All acts or parts of acts which are inconsistent with the provisions of this act are hereby repealed."

87 UNIFORM ACr \& 17: "Time of taking effect. This act shall take effect . . . and shall apply to all estates of tenants or remaindermen which become legally effective after that date."

88 See Trustees of Dartmouth College v. Woodward (1819) 17 U.S. (4 Wheat.) 517; Bradley v. Lightcap (1904) 195 U.S. 1; Coolidge v. Long (1931) 282 U. S. 582 ; Home Building \& Loan Ass'n v. Blaisdell (1934) 290 U. S. 398. 
amendable in respect of matters covered by the Act. ${ }^{89}$ The subjoined draft of section 17 incorporates this suggestion. ${ }^{20}$

The foregoing suggestions, made tentatively and with a diffidence suitable to the importance and difficulty of the topic, are submitted in the hope that their consideration may open avenues of inquiry through whose exploration the Uniforn Act may be improved and its usefulness increased. The problems involved have their doctrinal aspects, but above all are intensely practical. In any given case, almost any theory having sufficient plausibility to command the allegiance even of a minority of courts or scholars will answer well enough from the standpoint of technique. Granting this, primary attention may be given to those functional tests through which energies and funds now wasted on doubts and conflicts may be released to enable trusts better to perform their office as social agencies. It is hoped that these comments may in some degree stimulate effort leading toward that objective.

Walter L. Nossaman.

Los ANgetes, Catifornia.

${ }^{89}$ For all practical purposes, the settlor of a revocable trust is, while living, the owner of the trustee property. Reinecke v. Northern Trust Co. (1929) 278 U.S. 339; Lawrence v. First Nat. Bank \& Trust Co. (1934) 266 Mich. 199, 253 N.W. 267; see Chase Nat. Bank v. United States (1929) 278 U. S. 327. To apply the same doctrine to trusts amendable in the respects mentioned seems but a slight extension of this familiar principle. See Porter v. Commissioner (1933) 288 U. S. 436; Sanford Estate v. Commissioner (C. C. A. 3d, 1939) 103 F. (2d) 81.

90 § 17: [Suggested revision]: This act shall appiy to all transactions by which a principal shall be established which become legally effective on or after the effcctive date of this act. It shall also apply to all revocable trusts existing on and prior to that date and to all other trusts to the extent to which they may be at that or any later time amendable by the settlor in respect of matters covered by this act; but provisions of such trusts inconsistent with the provisions of this act shall govern to the extent provided in section 2 .

A provision suggested in Oklahoma (aiso in a draft prepared in Californa) in 1939, and approved by the Committee on Federal Legislation, Trust Division, American Bankers Association [81 Trust BuLr. AMr. Bankers Ass'N (1939) 4] making the new statute applicable, annong other cases, insofar as its terms "do not impair the obligation of contract or deprive persons of property without due process of law," seems impractical because vague and likely to be provocative of litigation. 